\title{
ORC3 wt Allele
}

National Cancer Institute

\section{Source}

National Cancer Institute. ORC3 wt Allele. NCI Thesaurus. Code C52314.

Human ORC3 wild-type allele is located in the vicinity of $6 q 15$ and is approximately $77 \mathrm{~kb}$ in length. This allele, which encodes orig in recog nition complex subunit protein, plays a role in the mediation of chromatin duplication. 